\title{
IT GOVERNANCE AND ERP POST-IMPLEMENTATION: ANALYSING THE IMPACT OF IT BUSINESS ALIGNMENT AND IT BENEFITS MANAGEMENT ON ERP OPERATION AND ENHANCEMENT
}

\author{
Rajesri Govindaraju ${ }^{1 *}$, I Nyoman Krisna Dwipayana ${ }^{1}$, Siti Yaumi Salamah ${ }^{1}$ \\ ${ }^{1}$ Industrial Technology Faculty, Bandung Institute of Technology \\ Jl. Ganesha 10, Bandung 40132, Indonesia
}

(Received: July 2017 / Revised: December 2017 / Accepted: March 2018)

\begin{abstract}
This study discusses the impact of IT governance on the routine operation and enhancement effectiveness in the ERP post-implementation phase. At this stage, at which an ERP system has been used to support a company's operations, the company needs to arrange for IT governance to be effective, because overall ERP benefits can only be achieved when the operating environment is supportive. Structure, process and relational mechanisms are important aspects of IT governance. This research is focused on the process aspect, which is closely related to the value achievement of an enterprise. The influence of two factors related to IT governance processes were investigated, namely IT business alignment and IT benefits management. The results of the study will provide companies with knowledge on how IT governance, particularly process-related issues, makes a contribution to the effectiveness of routine operations and enhancement during the ERP post-implementation stage. Furthermore, this knowledge can be used to help companies benefit fully from ERP implementation.
\end{abstract}

Keywords: Enhancement; ERP post-implementation; IT benefits management; IT-business alignment; IT Governance; Routine operation

\section{INTRODUCTION}

Enterprise Resource Planning (ERP) systems are configurable information system applications that integrate information and information-based processes within and across functional areas in an organization (Kumar \& Hillegersberg, 2000). ERP implementation is a process of implementing systems related to IT that are considered complex and costly for a company (Zhang et al., 2003; Nah \& Lau, 2001). With the massive amount of investment that is made by a company to implement an ERP system, its impact on the productivity and continuity of a company's business performance is often questioned. This phenomenon is referred to as the productivity paradox or the IT black hole (Hajli et al., 2015). It has arisen because companies assume that when ERP has been successfully implemented or has reached the Go Live phase, they will instantly enjoy the full benefits of ERP.

The identification of critical success factors (CSFs) for the success of ERP implementation has been studied intensively by many researchers (e.g. Zhang et al., 2003; Leopoldo \& Colmenares, 2004; Ehie \& Madsen, 2005; Nah \& Lau, 2001; Motwani et al., 2005). Many studies (e.g. Genoulaz et al., 2005; Govindaraju, 2012; Simatupang et al., 2016) have emphasised that going live is not the end of an ERP implementation. On the contrary, it is the end of the beginning of a

*Corresponding author's email: rajesri_g@ti.itb.ac.id, Tel: +62-22-2509164, Fax: +62-22-2509164 Permalink/DOI: https://doi.org/10.14716/ijtech.v9i3.1205 
journey towards improvement, innovation and agility. The complete benefit of an ERP system can be achieved by synergizing people, processes and technology at the stage when ERP becomes operational. Therefore, the full business benefits of ERP can only be enjoyed by a company if it stays focused and makes continuous efforts in the stage after implementation (installation) has been completed, which is called the post-implementation phase (Deloitte, 1999). ERP post-implementation is also referred to as the phase after selection and configuration of the ERP system, user training, and the going live stage. Even though studies concerning the ERP post-implementation phase, or the phase after going live, have been made, they have received little attention (Genoulaz et al., 2005).

Considering the fact that it is often difficult to successfully implement IT, despite the heavy investment put into it, it is important to have good governance for this implementation, which is known as IT governance. IT governance is implemented to ensure that IT investments are directed and made in a manner that achieves business value (Lunardi et al., 2014). This allows companies to gain maximum benefits from their information systems. Based on Van Grembergen (2004), IT governance in this study is defined as the relational structure of IT and the business, process and relational mechanisms of stakeholders, which direct and organize the company in order to achieve its goals by providing value addition from the use of information technology.

The ERP post-implementation phase requires effective IT governance because it is only then that a company can obtain the full benefits of ERP. The company needs to know how IT governance contributes to the effectiveness of the ERP post-implementation phase so that it gains the whole benefits of ERP. The integration of structural, process and relational mechanisms is needed to execute IT governance effectively (Peterson, 2004). The main reference of the IT governance framework in this study is one that is based on the integration and harmonization of IT decision process, structural and control mechanisms, as developed by Van Grembergen (2004), Peterson (2004), Weill and Ross (2004) and Symons (2005).

According to Van Grembergen (2004), IT governance can be developed using a combination of structural, process and relational mechanisms. IT governance design is affected by internal and external factors, which occasionally collide with each other. Therefore, finding an appropriate mechanism is a complicated process. Moreover, what works strategically for one company does not always work for another (Van Grembergen, 2004). Similar to Van Grembergen (2004), Peterson (2004) explains that IT governance capabilities consist of the following:

- Structure-related capability, with roles and formal positions, committees and councils as the key mechanisms;

- Process-related capability, which includes strategic IT decision making and monitoring; and

- Relational capability, of which the key mechanisms are business-IT partnerships and shared learning.

Symons (2005) states that every IT governance framework must include three propositions: the governance structure (the "who" of IT governance), the governance process (the "how" of IT governance), and governance communication in order to measure and communicate overall performance.

Among the three components of IT governance mentioned above, which are structural, process and relational mechanisms, the structural and process capabilities tend to be mandatory and tangible in designing effective IT governance, hence at a minimum level organizations need to have these capabilities in place (Peterson, 2004). The mechanisms related to structure, such as roles, responsibilities and IT committees, are closely related to the process capability. This IT structure is the foundation that supports the IT activities and processes taking place within the structure. A clear definition of the processes and their requirements will help to analyse the 
required structures more precisely. At the same time, process capability is focused on the integration of business and IT decisions, or the alignment of strategic IT investments with the strategic goals and objectives of the company (Peterson, 2004). This capability is still a common issue found in enterprises due to the complexity of IT and business alignment. Furthermore, in the post-implementation phase, companies tend to neglect the fact that it is important to know the direction of the development and improvement of the system implemented so that it will have an impact on the business. Therefore, companies need to address the challenges of how to organize the processes that will affect the achievement of business values. This research aims to focus on the process mechanisms of IT governance and consider their contribution to the effectiveness of ERP post-implementation. In this way, the implementation of ERP, which requires significant investment, can be directed in order to provide maximum advantages for the company's business performance. The question addressed in this research is formulated as follows: "How can process-related IT governance strategies affect the effectiveness of routine operations and enhancement in ERP post-implementation?"

\section{METHODOLOGY}

\subsection{Research Propositions}

Referring to the framework for IT governance (Van Grembergen, 2004), it is important to consider the issues related to the structural, process and relational mechanisms, in order to implement IT governance effectively in an organization. As IT governance focuses on the issues in achieving the link between business and IT (De Haes \& Van Grembergen, 2004), this study is focused mainly on the process capability, which involves the aspect of alignment and is directly related to the fulfilment of business value.

Several studies have mentioned a number of mechanisms that are related to the process capability, which are categorized as strategic IT decision making and strategic IT monitoring processes (Van Grembergen, 2004). Accordingly, the aim is to analyze the influence of the two key mechanisms related to the processes, namely IT-business alignment, as a mechanism related to the IT decision-making process, and IT benefits management, as a mechanism related to the IT monitoring process.

IT-business alignment is one of the mechanisms used in the strategic IT decision-making process (Van Grembergen, 2004; Peterson, 2004) and is one of the most commonly used mechanisms in IT governance (Weill \& Ross, 2004). According to Van Grembergen (2004), ITbusiness alignment is the integration of business and IT decisions, or the alignment between IT investment strategy and the strategic goals and objectives of a company. Studies have shown that the alignment of business and IT is the key element in IT governance, and which leads to the achievement of organization's business values, strategies and goals, and management support (Cragg et al., 2002; De Haes \& Van Grembergen, 2004; Cohen, 2008; Lunardi et al., 2014). As the foundation for IT governance, IT strategies and plans need to be aligned with strategic business objectives so that the implementation of IT provides the capability to deliver business value (Wilkin, 2010). Therefore, this mechanism is selected as that which needs more attention paid to it for the effectiveness of IT governance.

Proposition 1: IT-business alignment will have a real impact on the effectiveness of ERP routine operation and enhancement in the post-implementation phase.

Beside IT-business alignment, another important mechanism to ensure that IT investment adds value to an organization is IT benefits management (Peterson, 2004; Serra \& Kunc, 2015; Terlizzi et al., 2017). This is an activity which monitors and tracks IT implementation in the form of the delivery of service and business benefits realization. The adoption of IT governance mechanisms formulate and formalize both the understanding and application of IT governance 
in a practical business environment, particularly regarding the maximization of IT benefits, among other areas (Wilkin, 2010). IT governance also needs to be able to assess whether the IT implementation is being properly managed and deployed by the IT department so that the project benefits are enjoyed (Terlizzi et al., 2017).

In order to effectively manage the benefits realization process of the ERP system, the company is required to have an IT benefits management mechanism (Badewi \& Shehab, 2015). It is vital that the benefits are defined and prioritized, and that action plans are created to achieve them; this needs to be done as a continuous process, since most of the benefits come after it has been implemented (Davenport et al., 2004). For these reasons, this study will discuss the influence of IT benefits management as a part of IT governance.

The mechanisms above will be assessed to establish the influence they have on the success of ERP post-implementation. The success of this will be measured by two factors, namely routine operation effectiveness and enhancement effectiveness. A routine operation is a period starting from going live to normal operation. Normal operation is a state in which the ERP system has been embedded into the daily operational routines of the company. This means that internal integration of the entire business process in the company has been achieved and the system is able to provide information to support effective decision making. The key activities in this stage are bug fixing and rework, system performance tuning, troubleshooting, process and procedure changes, additional or re-training for super users and end users, and postimplementation review (Markus \& Tanis, 1999; Ross \& Vitale, 2000; Palaniswamy \& Frank, 2002). Palaniswamy \& Frank (2002) further define the indicators of effectiveness for routine operation, which are the realization of standardization of data, processes and application; realization of the internal integration of business process and information systems; increase in ERP system usage; and the realization of the benefits.

Enhancement, on the other hand, is the stage after ERP has become the daily operational routine in companies, when they are trying to improve the ERP module functional capabilities and to integrate other systems into the ERP system to gain new benefits, such as SCM, CRM, business intelligence and B2B. Several studies had defined the key activities for enhancement; namely, increasing ERP system capability continuously; improving business processes; integrating ERP with other applications as complementary solutions; upgrading or technology migration; and developing new expertise for end-users (Deloitte, 1999; Markus \& Tanis, 1999; Palaniswamy \& Frank; 2002, Ross \& Vitale, 2000; Ahituv et al., 2002). Based on these activities, several indicators of enhancement effectiveness have been introduced. These are improvements in ERP module functional capability; ERP application and infrastructure upgrades; integration of ERP and other applications; and the establishment of relevant IT expertise.

Proposition 2: IT benefits management that is well-implemented will have a positive impact on the effectiveness of ERP routine operation and enhancement in the post-implementation phase.

\subsection{Research Method}

The research strategy selected for this study is the case study. A positivist case study is conducted, focusing on the empirical testability of theories, and working in a deductive way to establish the cause-effect relationship as the foundation of generalized knowledge. The study is exploratory in nature; a single case study approach is used to conduct deeper research on companies that have entered the ERP post-implementation phase. There are five essential components in the research design for a case study, namely the research question, research proposition, unit of analysis, logical relationship between data and proposition, and the criteria to interpret the findings. In this study, the propositions were formulated to reflect on the importance of the theoretical problems, as well as to help the researchers in finding relevant 
data.

The selection of a case company for this research was made based on the category of ERP implementation system stages developed by Hawking and Stein (2004), which are:

- Beginning: ERP has been implemented in the past 12 months

- Consolidating: ERP has been implemented for between 1 and 3 years

- Mature: ERP has been implemented for more than 3 years

The post-implementation phase of the ERP system falls into the category of an enterprise that has implemented ERP for 1 to 3 years or more. PT Garuda Maintenance Facility AeroAsia (GMFAA) was selected as the single case for this study. GMFAA is an airplane MRO (Maintenance, Repair and Overhaul) company. It has implemented nine SAP R/3 modules and three large add-ons. The implementation of SAP R/3 has covered 50 major business processes and more than 500 business events and has been employed by 400 users.

The respondents in this study come from the IT department, SAP CCC business unit, business users and service unit. Interviews are one of the essential sources of information for the study. They can be categorized as open-ended in nature and focused. An open-ended nature means that the researcher asks the key informants about certain issues. These informants are critical to the success of the case study, because they provide support by not only sharing the necessary knowledge with the researcher, but also by recommending other sources that can add evidence. The key informants in this study are the PM SAP (competence center) and GM IT (CIO of GMFAA). Focused interviews mean that the respondent is interviewed in a short time. The interview was conducted in an informal setting, and the questions were drafted based on case study protocol, which is presented in Appendix 1.

Other sources of information are direct observations and company documentation. Direct observations were made by directly visiting the business units where SAP applications were being used and visiting the IT department, as well as the SAP CCC Business Unit. Activities undertaken included attendance at several meetings and SAP training programs. Documentation was available in various forms. The types of documents included organization structure, strategy maps of each business unit, SAP project documentation and meeting notes.

Case study analysis was conducted based on the theoretical propositions. Pattern-matching is the most important strategy for case study analysis (Yin, 2002). This logically compares particular empirical data with the proposition put forward. Internal validity can be improved with a matching pattern. If the comparison pattern between the empirical data and the proposition does not match, the next analysis process, which is explanation of the cause-effect relationship between the independent and dependent variables, cannot be done.

\section{RESULTS AND DISCUSSION}

\subsection{Analysis of Proposition 1}

Figure 1 shows the relationship between IT-business alignment and the effectiveness of routine operation and enhancement in the post-implementation stage. The effectiveness of IT-business alignment strategy will first have an impact on the following two areas: (1) ensuring that the operational activity using SAP has a role in the achievement of business goals; and (2) that the staff from the business unit and IT unit will be able to work together in the SAP competence center, to support the use of the ERP system continuously. Furthermore, the fact that the operational activity using SAP is in line with the needs of the business goals will then increase the effectiveness of routine operation in the following ways: (1) increase in SAP usage; and (2) increased SAP benefit realization. 
If the business unit and IT unit are working together effectively and continuously in the SAP competence center, this will have an impact on the effectiveness of routine operation in the following two ways: (1) achievement of a stable SAP system; and (2) internal integration of business processes and the information system. Moreover, the effectiveness of the collaboration between IT and business units in the SAP competence center will also have an impact on the enhancement effectiveness in the following three ways: (1) improving the functional capabilities of SAP modules; (2) support system and infrastructure upgrades; and (3) support for the integration of SAP with other applications.

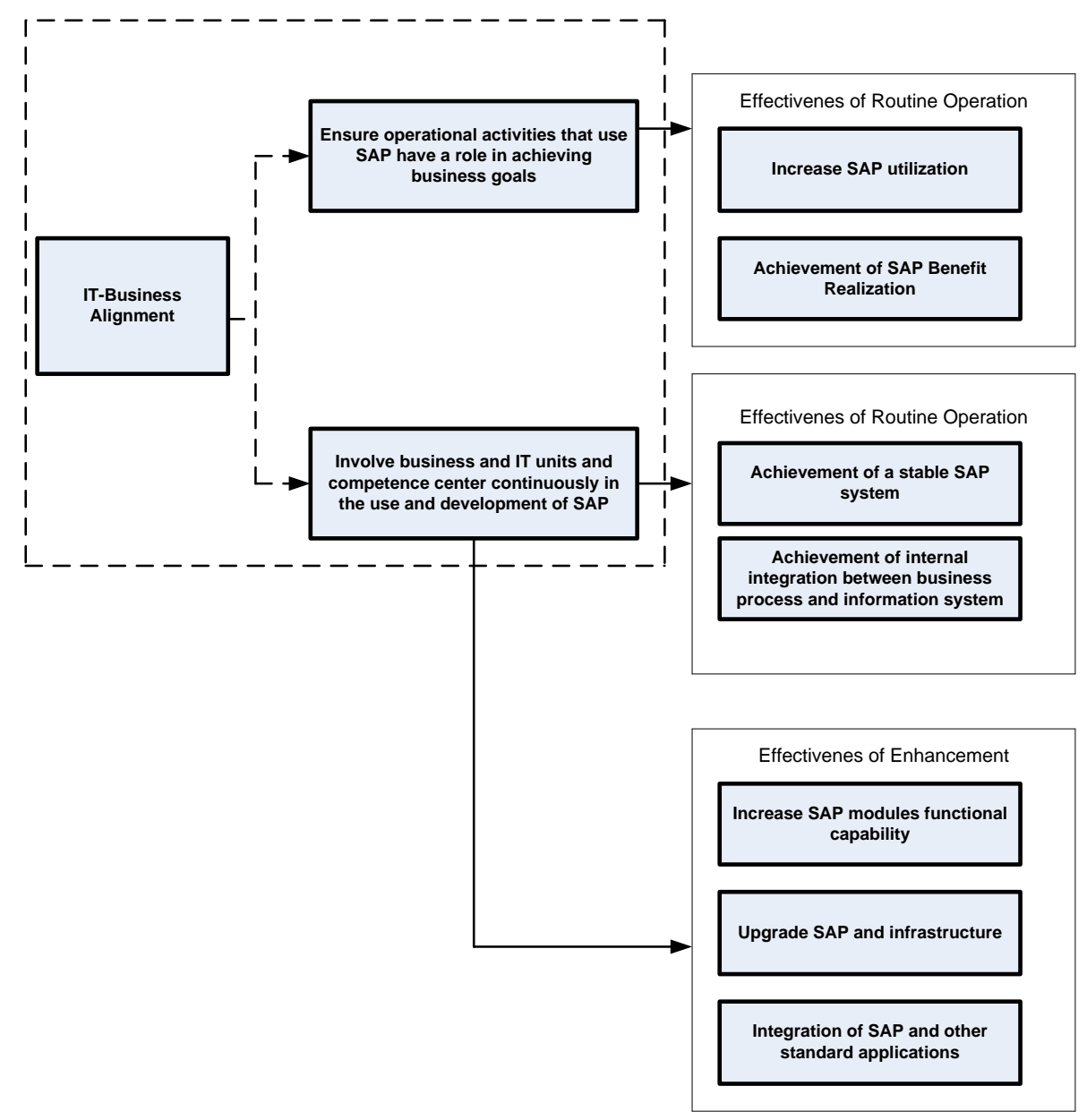

Figure 1 Relationship between IT-business alignment and the effectiveness of ERP routine operation and enhancement

\subsection{Analysis of Proposition 2}

Figure 2 shows the relationship between IT benefits management and the effectiveness of routine operation and enhancement. The effectiveness of IT benefits management will first have an impact on the following three areas: (1) guiding the company in undertaking benefits monitoring; (2) supporting the company in taking corrective actions; and (3) supporting the company in identifying ideas for system enhancements. The benefits monitoring activities will also have an impact on the ability to identify problems that inhibit the realization of benefits. By identifying the problems occurring, including the areas in the company where the benefit is not being realized; who is not gaining from the benefit; who is responsible for the unrealized benefit; what action is needed; and when the benefit needs to be realized, the company can identify the necessary corrective actions to be taken in order to realize the benefits from ERP usage. These conditions will help the company to achieve a stable SAP system. Moreover, the 
corrective actions taken by the company will also help it to realise its KPIs, which will then support the benefit realization in line with expectation.

Finally, the fact that the IT benefits management process has supported the identification of ideas about ERP system enhancements will have an impact on ERP enhancement effectiveness, including the enhancement of the functional capabilities of the ERP modules, ERP systems and infrastructure upgrades, and the integration of the ERP system with other applications.

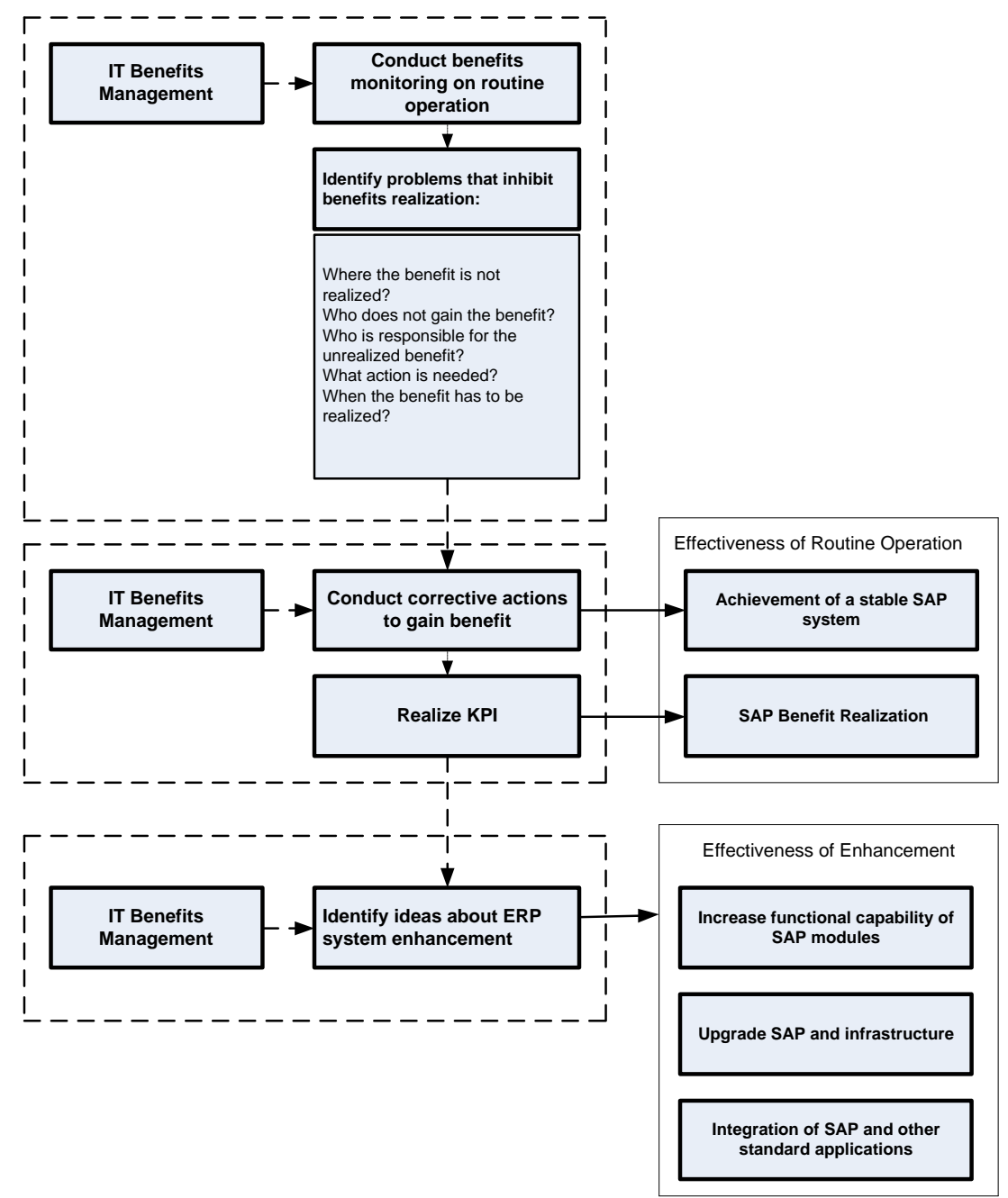

Figure 2 The relationship between IT benefits management and the effectiveness of ERP routine operation and enhancement

\section{CONCLUSION}

The study has found that IT-business alignment and IT benefits management both support the effectiveness of ERP routine operation and enhancement in the post-implementation phase, in a number of ways. IT-business alignment has an impact on the effectiveness of routine operation by fulfilling four indicators of routine operation effectiveness, namely the achievement of a stable ERP system, an increase in ERP usage, ERP benefits realization, and attainment of the internal integration of business processes and information system. IT-business alignment also has a positive influence on enhancement effectiveness, as can be seen in several aspects, including the improvement in the functional capabilities of SAP modules, integration of ERP with other applications, and upgrades to ERP application and infrastructure. 
IT benefits management has a positive impact on the effectiveness of routine operation and enhancement. It plays a role in achieving routine operation effectiveness, particularly a stable ERP system and the ability to realize a number of ERP benefits. The enhancement effectiveness is affected in terms of improvement in the functional capabilities of the SAP modules, integration of ERP with other applications, and upgrades to ERP application and infrastructure.

Since this study is focused on two factors related to processes in IT governance frameworks, future study could be conducted on elaborating further the influence of other factors related to processes. In addition, structure-related issues are also important for exploration in future studies, in order to obtain a more comprehensive overview of how organisations can internally rearrange their structure and processes in order to realise the potential benefits offered by ERP implementation.

\section{REFERENCES}

Ahituv, N., Neumann, S., Zviran, M., 2002. A System Development Methodology for ERP Systems. Journal of Computer Information Systems, Volume 42(3), pp. 56-67

Badewi, A., Shehab, E., 2015. The Impact of Organizational Project Benefits Management Governance on ERP Project Success: Neo-Institutional Theory Perspective. International Journal of Project Management, Volume 34(3), pp. 412-428

Cohen, J.F., 2008. Contextual Determinants and Performance Implications of Information Systems Strategy Planning within South African Firms. Information \& Management, Volume 45(8), pp. 547-555

Cragg, P., King, M., Hussin, H., 2002. IT Alignment and Firm Performance in Small Manufacturing Firms. The Journal of Strategic Information Systems, Volume 11(2), pp. $109-132$

Davenport, T.H., Harris, J.G., Cantrell, S., 2004. Enterprise Systems and Ongoing Process Change. Business Process Management Journal, Volume 10(1), pp. 16-26

De Haes, S., Van Grembergen. W., 2004. IT Governance and Its Mechanisms. Information Systems Control Journal, Volume 1, pp. 1-7

Deloitte Consulting, 1999. ERP's Second Wave: Maximizing the Value of Enterprise Applications and Processes

Ehie, I.C., Madsen, M., 2005. Identifying Critical Issues in Enterprise Resource Planning (ERP) Implementation. Computer in Industry, Volume 56(6), pp. 545-557

Genoulaz, V.B., Millet, P.A., Grabot, B., 2005. A Survey on the Recent Research Literatur on ERP Systems. Computers in Industry, Volume 56(6), 510-522

Govindaraju, R., 2012. Enterprise Systems Implementation Framework: an Organisational Perspective. Procedia-Social and Behavioral Sciences, Volume 65, pp. 473-478

Hajli, M., Sims, J.M., Ibragimov, V., 2015. Information Technology (IT) Productivity Paradox in the $21^{\text {st }}$ Century. International Journal of Productivity and Performance Management, Volume 64(4), pp. 457-478

Hawking, P., Stein, A., 2004. Revisiting ERP Systems: Benefit Realisation. In: Proceedings of the $37^{\text {th }}$ Hawaii International Conference on System Sciences

Kumar, K., Hillegersberg, J.V., 2000. ERP Experiences and Evolution. Communications of the ACM, Volume 43, pp. 23-26

Leopoldo, E., Colmenares, G., 2004. Critical Success Factors of Enterprise Resource Planning Systems Implementation in Venezuela. In: Proceedings of Tenth Americas Conference on Information Systems, New York

Lunardi, G.L., Maçada, A.C.G., Becker, J.L., 2014. IT Governance Effectiveness and Its Antecedents: An Empirical Examination in Brazilian Firms. In: the $47^{\text {th }}$ Hawaii International Conference on System Sciences (HICSS), pp. 4376-4385 
Markus, M.L., Tanis, C., 1999. The Enterprise System Experience-From Adoption to Success, Chapter 10. Claremont Graduate University, California, pp. 173-207

Motwani, J., Subramanian, R., Gopalakrisnha, P., 2005. Critical Factors for Successful ERP Implementation: Exploratory Findings from Four Case Studies. Computers in Industry, Volume 56(6), pp. 529-544

Nah, F.F.H., Lau, J.L.S., 2001. Critical Factors for Successful Implementation of Enterprise Systems. Business Process Management Journal, Volume 7(3), pp. 285-296

Palaniswamy, R., Frank, T.G., 2002. Oracle ERP and Network Computing Architecture: Implementation and Performance. Information Systems Management, Volume 19(2), pp. 53-69

Peterson, R., 2004. Crafting Information Technology Governance. Information Systems Management, Volume 21(4), pp. 7-22

Ross, J.W., Vitale, M.R., 2000. The ERP Revolution: Surviving vs Thriving. Information System Frontiers, Volume 2(2), pp. 233-241

Serra, C.E.M., Kunc, M., 2015. Benefits Realisation Management and its Influence on Project Success and on the Execution of Business Strategies. International Journal of Project Management, Volume 33(1), pp. 53-66

Simatupang, T., Govindaraju, R., Amaranti, R., 2016. Change Management Perspectives in an ERP Module Implementation: A Case Study in a Telecommunication Company. Jurnal Teknik Industri (Journal of Industrial Engineering), Volume 18(1), pp. 51-60

Symons, C., 2005. IT Governance Framework, Forrester best Practice, Volume 29

Terlizzi, M.A., Albertin, A.L., Moraes, H.R.D.O.C.D., 2017. IT Benefits Management in Financial Institutions: Practices and Barriers. International Journal of Project Management, Volume 35(5), pp. 763-782

Van Grembergen, W., 2004. Strategies for Information Technology Governance. Idea Group Publishing

Weill, P., Ross, J.W., 2004. IT Governance: How Top Performers Manage IT Decision Rights for Superior Results. Harvard Business School Press

Wilkin, C.L., Chenhall, R.H., 2010. A Review of IT Governance: a Taxonomy to Inform Accounting Information Systems. Journal of Information Systems, Volume 24(2), pp. 107 146

Yin, R. K., 2002. Case Study Research, Design and Methods. $3^{\text {rd }}$ ed., Newbury Park, Sage Publications

Zhang, L., Matthew, K.O., Lee, Z.Z., Banerjee, P., 2003. Critical Success Factors of Enterprise Resource Planning Systems Implementation Success in China. In: Proceedings of the $36^{\text {th }}$ Hawaii International Conference on System Sciences 


\section{APPENDIX 1 \\ CASE STUDY PROTOCOL}

The data which needed to be collected for the study is presented in Table A1.

Table A1 Data collected for the research

\begin{tabular}{|l|l|l|}
\hline Stages & Data & Sources \\
\hline Preliminary investigation & $\begin{array}{l}\text { Company vision } \\
\text { Company mission } \\
\text { Organisation structure }\end{array}$ & Company document \\
\hline ERP project (SAP R/3) & $\begin{array}{l}\text { Background } \\
\text { Overview of project plan and } \\
\text { execution }\end{array}$ & $\begin{array}{l}\text { Company document } \\
\text { Interview }\end{array}$ \\
\hline ERP (Post-implementation) & $\begin{array}{l}\text { Routine operation } \\
\text { Enhancement }\end{array}$ & $\begin{array}{l}\text { Company document } \\
\text { Interview }\end{array}$ \\
\hline IT governance & $\begin{array}{l}\text { IT Business Alignment } \\
\text { IT Benefits Management } \\
\text { Communication }\end{array}$ & $\begin{array}{l}\text { Company document } \\
\text { Interview }\end{array}$ \\
\hline
\end{tabular}

Those interviewed were divided into two groups, namely SAP managers and SAP users. Table A2 shows the interview respondents who became the sources for the data collected in the research.

Table A2 Interviewees

\begin{tabular}{|l|l|l|}
\hline SAP managers & SAP users & \multicolumn{2}{|c|}{} \\
\cline { 2 - 3 } & Business unit & Service Unit \\
\hline 1 PM SAP (CCC SAP Garuda) & 1 GM and 1 Manager Component Shop & 1 GM Marketing \\
1 GM IT & 1 GM and 1 Manager Base Maintenance & 1 GM Financial \\
1 Staff SAP & 2 Staff end user & 2 Staff end user \\
\hline
\end{tabular}

The main questions used in the interviews are listed in Table A3. 
Table A3 Interview questions

\begin{tabular}{|c|}
\hline Introduction \\
\hline - What are the roles and responsibilities of this unit? \\
\hline SAP project \\
\hline $\begin{array}{l}\text { Background } \\
\text { - What are the motivations for implementing ERP in the company? } \\
\text { What were the main benefits to be achieved? }\end{array}$ \\
\hline $\begin{array}{l}\text { Strategy } \\
-\quad \text { Who were responsible for the ERP implementation project? } \\
-\quad \text { Who were involved in the project? } \\
\text { - } \quad \text { What were the roles of the SAP centre? } \\
\text { - What were the roles of the business units? } \\
\text { - What were the roles of the SAP IT Dept.? } \\
\text { - What type of implementation strategy was used, a Bigbang approach or Phased approach? }\end{array}$ \\
\hline $\begin{array}{l}\text { Stages } \\
-\quad \text { Which modules were implemented and why? } \\
-\quad \text { How was the project arranged in terms of stages? } \\
\end{array}$ \\
\hline $\begin{array}{l}\text { Obstacles } \\
-\quad \text { What were the main obstacles in the project? }\end{array}$ \\
\hline SAP Post Implementation \\
\hline Routine operation \\
\hline $\begin{array}{l}\text { How far were the company business processes supported by SAP? } \\
\text { - } \quad \text { Are all units using SAP? } \\
\text { - What are the roles of SAP CC in the routine operation process? } \\
\text { - What problems were faced regarding the routine operations of SAP? } \\
\text { - How is the relationship and partnership between IT and SAP CC? }\end{array}$ \\
\hline Enhancement \\
\hline $\begin{array}{l}\text { - What are the sources of demands for new ERP functionalities? } \\
\text { - What are the obstacles faced in improving SAP functionalities? } \\
\text { - What strategy does SAP CCC want to adopt to improve SAP functionalities? } \\
\text { - What is the role of the IT department in the enhancement process? } \\
\text { - What are the problems faced in the enhancement process? }\end{array}$ \\
\hline IT Governance \\
\hline $\begin{array}{l}\text { IT Business alignment } \\
-\quad \text { What efforts were made to synergize the business strategy and IT strategy? } \\
-\quad \text { What is the company doing to meet the business unit's requirements? } \\
-\quad \text { How does IT Business alignment influence the routine operations? } \\
-\quad \text { How does IT Business alignment affect enhancement? }\end{array}$ \\
\hline $\begin{array}{l}\text { IT Benefits management } \\
-\quad \text { What efforts were taken to manage benefits and to realize the benefits from SAP usage? } \\
-\quad \text { How does IT benefits management affect routine operation processes and results? } \\
\text { - How does IT benefits management affect the enhancement process and results? }\end{array}$ \\
\hline
\end{tabular}

